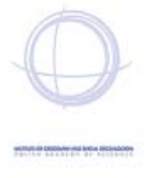

\title{
THE STAMPS OF THE AUTHORITY AND OWNERSHIP IN CULTURAL LANDSCAPE
}

\section{Joanna Plit}

Institute of Geography and Spatial Organization

Polish Academy of Sciences

Twarda 51/55, 00-818 Warsaw: Poland

e-mail address: plitjo@twarda.pan.pl

\begin{abstract}
Cultural landscape can be treated as an iconographic representation of regional history. Landscape preserves traces of magnates' aspirations regarding spatial domination and the delimitation of their territorial borders. These are the traces of inspiration and of ways in which to exercise power, evidence of their intentions to predominate, of their wish to obtain blind obedience, as well as to stir up envy and demonstrate distinctiveness. This paper has therefore sought to determine which features of authorities and of owners are discernible in the cultural landscapes of Poland.
\end{abstract}

\section{Key words}

marks of branding • cultural landscape • Poland

\section{Introduction}

The cultural landscapes of Central Europe have preserved traces of ancient power systems, monuments of the past, and structures inherited from historical epochs. The respective traces are imprinted in buildings, in spatial patterns and in symbolic signatures. They can be reconstructed through analysis of the locations and magnitudes of architectural objects, the spatial and functional settings of towns, and the courses taken by roads, divisions and outlines of land plots (Tilley 1994, 2008; Muir 2000; Van Dyke 2008). They are also frequently reflected in changes in vegetation and in the animal world. Thus every epoch and every kind of authority tries to leave traces of its existence in the landscape, as well as to implant the philosophical and religious system followed at the time and to enforce its aesthetic principles. The impact of rulers and owners on the landscape is distinct for periods not far back in time, as traces of past epochs are steadily being wiped out as a result of successive overlaying, modifications, and sometimes even the quite conscious destruction of older buildings and spatial patterns. "The longer and the richer the activity of a given society in its geographical environment and the higher the level of its technical development, the more complicated are the overlaying element structures and complexes, appearing in the landscape" (Dobrowolska 1948: 157).

This articlet. has sought to answer questions regarding the features of authority and ownership that remain imprinted even in today's cultural landscape in the countries of Central Europe, as

\footnotetext{
${ }^{1}$ A first, simplified version of this article was published in Prace Komisji Krajobrazu Kulturowego PTG (Plit 2011).
} 
well as the ways in which these elements may be 'read off'. A theoretical basis here is offered through the extrapolation of the humanistic geography approach taken by Tuan $(1978,2005)$ when it comes to the analysis, assessment and valuation of cultural landscapes, as well as the interpretation of their evolution through history. The article is a proposed means by which to order and organise individual subjective observations and feelings on the part of the author as regards regional physiognomy, spatial configurations, land use, landscape architecture, preserved monuments and even changes in the species composition of flora and the courses of borders.

The methodology of the work described here was a critical analysis and ordering of the numerous aforementioned own observations of the author, together with facts drawn from the literature. Efforts were made to seek out causes, to interpret and to generalise on the basis of data gathered. A holistic, multi-stranded analysis that links knowledge from various scientific disciplines (relating to geography, history, sociology, biogeography and landscape architecture) with a view to space being described from the point of view of the history of civilisation must by definition recall and make reference to the work by Braudel (1969) and the French Annales school. However, one difference would relate to the fact that the analysis presented here puts most emphasis on geographical (i.e. spatial and landscape-related) elements, as opposed to the historical.

In this work, the term cultural landscape is also as conceived very broadly, which is to say as a resultant of the mutual impacts of the forces of nature and human economic and social activity in all its complexity and wealth of cultural conditioning (Myga-Piątek 2001, 2012). Cultural landscape arose and evolved through a historical process, with successive metamorphoses or overlayings constituting its depth. "A cultural landscape is an historically-formed fragment of the geographic surface resulting from the emergence of the effects of environmental and cultural actions, making a specific structure apparent in regional differences and perceived as an individual physiognomy" (Myga-Piątek 2001: 165).

The issue under discussion here is of a universal nature, such that the concrete situations selected and described to illustrate more widelyapplying regularities are indeed regarded as both characteristic and representative. That said, it is clear that most of the examples presented here are from Poland.

\section{Demonstrating importance, manifesting rule}

Authorities of both lay and clerical character, in relation to the subjects resemble the rich with respect to the poor in seeking to emphasise their importance through physical domination. For preference, castles, monasteries and palaces were always located on isolated elevations, high escarpments or islands, within open or semi-open spaces. Such a location was conditioned, not only by defence-related aspects, but also by a wish to exert dominance over the neighbourhood. High and imposing structures were built of resistant materials, often with towers, from which a far view could be had, but which could at the same time be seen from far away, and heard from far away (this particular significance being traceable with respect to the role of church bells, chimes, bugle-calls, etc.) (Fig. 1). This manner of demonstrating importance (and, using the same device - of checking on what subjects do, and on whether an enemy is or is not in sight) can be observed in all epochs, in numerous cultural environments. Domination over the neighbourhood and the inaccessibility of power were also emphasised by the heights of multi-storey buildings and the walls surrounding them. In towns, in the central place of the market square, imposing town halls were constructed, with towers in which clocks and carillons were installed, and bugle-calls were sometimes sounded regularly. Their location and aspect attested to the significance, wealth and thrift of the local authorities. In later periods, public buildings of various kinds (schools, post offices, courts, houses of parliament, ministries and party $\mathrm{HQs}$ ) were to be distinguished by their imposing looks. They were made of solid material, stone or brick (Fig. 2). Contemporarily, we can also observe symptoms of the demonstration of domination on the part of those who rule or otherwise exert power. The so-called Palaces of Culture, of Stalinist origin, dominating for decades over Minsk (Belarus) and Warsaw, overwhelm with their enormous dimensions, in a similar way to the great mass of the Temple of Divine Providence currently being constructed in Warsaw. The downtown areas of cities are witnessing a sprouting of immensely tall apartment and office blocks, seats of banks and 


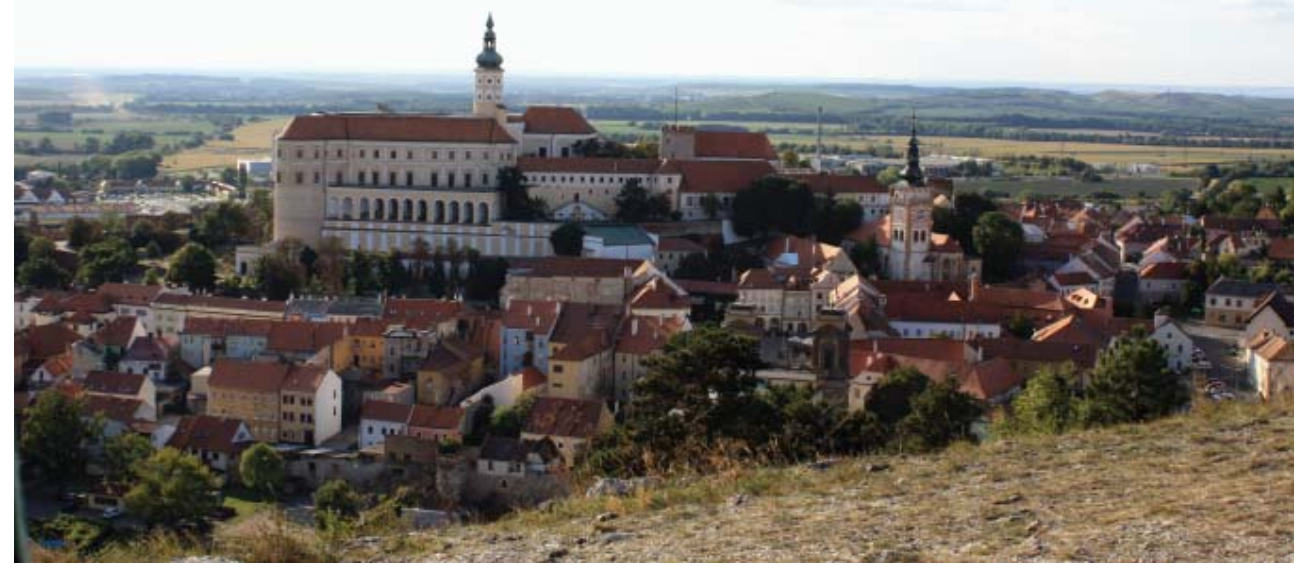

Figure 1. The characteristic location, sizes of buildings, and pomp (of castle and church alike) in the panorama of Mikulov (Czech Republic) do much to document who was exercising power.

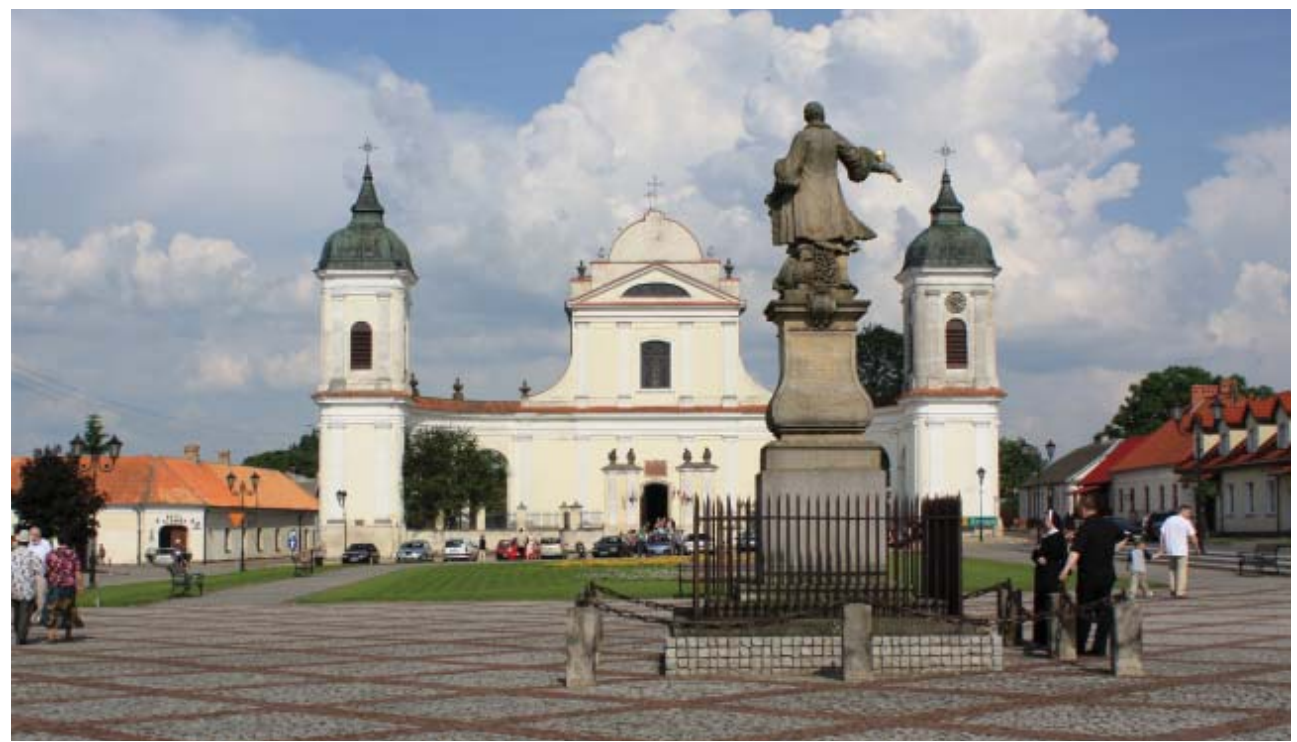

Figure 2. The Market Square in Tykocin features disproportion between the low-level construction typical of a small provincial town and the mammoth church. The square hosts a statue of Stefan Czarniecki - the landowner here in the 17 th century.

insurance companies, the intention again being to underline significance and to increase the splendour of the reborn capitalism on post-communist territory (Czepczyński 2006).

Another sign of the demonstration of power in landscape is the occupation of 'better' places by representatives who rule (or are wealthy), with the simultaneous expulsion of mere subjects to worse locations. It must be noted at this point that the criteria by which 'better' sites were distinguished changed down the centuries - in olden times sites with defensive properties were preferred, also fertile ones with easy access to water, while later on the aspect of defence lost in significance, while 
distance from the centre and transport accessibility were seen as increasingly important.

The structure to the use of land beyond suburban and industrial areas preserves ancient property divisions, despite the changes wrought as peasants were affranchised, land consolidated and agrarian reforms implemented. In the local landscape, the specific features of property divisions are emphasised by ploughing terraces, lines of bushes along balks, as well as road gullies. Large, fertile fields, situated on uplands or in valley bottoms belonged to the powerful (both in older times and nowadays). Peasant plots, pushed into the less-fertile areas, have been split up over time into narrow strips (belonging to numerous and poor owners), forming in the landscape a picturesque mosaic composed of patches of such strips. Such a structure to the rural landscape that long characterised Central Europe (even into the 20th century) is now best preserved in Poland and Lithuania - in the former case through the working of historical processes. ${ }^{2}$

It is worth underlining that lands formerly in the possession of the Church can be distinguished in the landscape, not only through the more fertile agricultural habitats, but also through a higher level of farming culture, with greater care taken and cleanliness maintained. A good example might be provided by Łowicz area - for 800 years the property of the Bishops of Poznań, until creation, in the course of the 19th century secularisation, of the Principality of Łowicz. Likewise, to this day one can readily trace in the terrain the lands belonging in olden times to the Benedictines from Sieciechów, the signs again entailing more careful

\footnotetext{
2 The ancient property and functional relations can be observed within the Pińczów Basin, where there remain, not only in the historical buildings, but also in the structure of the landscape, elements of the large landed estates dating back to the Pińczów estate entail (Kostrowicki \& Solon 1994). In Podlasie region the pattern of settlements and the divisions of land reveal features of the royal villages established in conformity with the land reforms of Queen Bona Sforza from the 16th century (Stepaniuk \& Gaweł 2006; Plit 2009). Landscape structure has also been preserved very well in Pomerania, in the Sławno area, where there remains unchanged the ancient setting of large-scale noble (Prussian junker) estates, rich peasant villages and the settlements of farmhands, despite the complete relocations of population, shifts in statehood, and radical changes in the systems of economy and management. Landscape structure was 'conserved' there, owing to the establishment of large-scale State Farms on the lands of former landowners, and, after the downfall of communism, the appearance of private owners of these same large estates.
}

cultivation and a functional pattern to the fields (Gacki 1872; Plit 2002).

\section{Demonstrating force, intimidating, compelling obedience}

Over the entire area of Central Europe one finds fortifications, strongholds, fortresses, castles, garrison buildings, military training grounds and belts of defensive lines of various kinds, all dating from different epochs. These entities, occupying large areas, have a clear landscape-related expression. Despotic rulers often tried to intimidate their subjects, enforcing obedience and their proper order (as regards language and religion). This finds reflection in the cultural landscape. The locations of many strongholds and fortresses indicate that some of them were constructed, not with the external enemy in mind, but in order to terrorise the local population (McMann 1994). Strongholds and garrison compounds located within urban areas were meant to provide for control over inhabitants suspected of disloyalty, while when built in points strategic from the transport point of view these would constrain the mobility of the population and flow of information, as well as making the organisation of mutinies and uprisings difficult.

These kinds of relationships - in this case between the Royal Castle hill and the city - can be observed in the pattern of Medieval Cracow and the Wawel Hill, along with the respective locations of particular objects. ${ }^{3}$ The fortified castle was erected on the hill in the immediate vicinity of the walled city, so as to be able to defend itself in the case of a mutiny or rebellion on the part of the townspeople. The wish to dominate, but also to keep power separated, can be seen through the locations of places of worship. The Royal Castle on the Wawel Hill has its cathedral, while the city has its magnificent Church of Our Lady. Rivalry was present even in the sphere of sound: the city established its bugle-call, sounded every hour from the tower of St. Mary's, while on the Wawel Hill the enormous Sigismundus Bell was hung. The strategic location of the Royal Castle with respect to the city was taken advantage of centuries later by the powers partitioning Poland, when an Austrian gar-

3 The preserved spatial pattern of Cracow was the basis for the city's being included on the UNESCO World Heritage List. 
rison was posted on the Wawel Hill almost up to the liberation in 1917.

18th-century Warsaw bore witness to the establishment, on a naturally isolated elevation not far from the Old Town - of a royal garrison and stables. In 1837, this Citadel was vastly extended and fortified by the Russian Tsar, the entire elevation being transformed into a fortress in which a large military contingent was stationed. The Citadel was supposed to intimidate the untamed city, to strengthen terror and amplify negative emotions. It was also used as a heavy-regime prison, and a place of summary executions.

\section{Demonstrating wealth while caring for the aesthetics of the surroundings}

Another reflection of power in landscape has been - and still is - meant as demonstration of special status (the conviction of the powerful that they rule, because they are 'well born', 'God's chosen', better ones - and so they ought to have more rights and be allowed more than others). This attitude is manifested in the landscape, in particular, through the showing-off of wealth and care for the aesthetics of the surrounding area. Castles, palaces, churches, monasteries, town halls, county halls and court buildings all fulfilled representation functions and were at the same time meant to impose, overwhelm, cause envy. Constructed of stone or brick, they stood out in terms of aesthetics of form (in line with the rules of the current fashion), good functional design of buildings and the entire property, rich fitting out of interiors and ornamentation. Architecture aimed at splendour, with care taken of the small details and small architectural elements. Of the objects erected in ancient epochs it is almost exclusively the historical buildings of the powerful that persist to this today, while of the wooden villages only the spatial pattern has remained in the landscape (since the oldest preserved peasant huts date back to the end of the 18th or the 19th centuries). Around the manor houses and palaces, ornamental plants were grown, forming well-designed compositions that featured a variety of colours and shapes, flower carpets were established, as well as broader landscape designs and far-off perspectives. For these purposes, plants originating from other regions, and even distant continents, were regularly brought to such parks and gardens. Chest- nut alleys and acacia groves appeared, Canadian spruce, box elder, sometimes gingko or tulip tree were also introduced. Nowadays, various conifers are fashionable, along with sumacs and rhododendrons. $^{4}$

The privilege of the authorities and owners lay in their right to leisure, entertainment and hunting. Woods and parks were the places of recreation. Across Poland, manor parks have been preserved, or at least traces of them, in the form of overgrown and unkempt wood-like areas surrounding the locations of manor houses. These parks would most often occupy rather small plots of 2 to 5 hectares, on fertile sites. Objects of this kind inevitably therefore gave rise to envy and a feeling of injustice among peasants and landless farmhands, especially during the period of land scarcity ('land hunger') in the 19th century and at the beginning of the 20th century, when every piece of land available was put to use in farming.

A further expression of large-scale property in the landscape of Poland is constituted by large, contiguous complexes of forest. Well-preserved forest areas correspond to the spatial pattern of the royal forests set aside for the hosting of large hunting events ${ }^{5}$ (like the Forests of Białowieża, Niepołomice, Kampinos, Kozienice, Kurpie, or Świętokrzyskie), or else the extensive property of monasteries (as in the case of the Augustów Forest), and the estates of magnates (as in the Forests of Pisz and Knyszyn, as well as the woodlands of the Roztocze Hills). These forest areas featured high natural richness, had a multiple-layered stand structure and encompassed differentiated habitats, with both fertile and poor, dry and wet. These distinct large forests were more carefully managed, better controlled, with exploitation of resources explicitly limited, i.a. by enforced bans on tree felling, and even on the possibility of entering forests. Nowadays, it is in these areas that the majority of Poland's National Parks have been established. This fact resulted, not only from a wish to preserve the wealth of nature, but also in

\footnotetext{
4 Some of the plants brought in to the parks acclimatised, and constitute nowadays a permanent element of the vegetation. Among these there are also some very expansive species like box elder, red (American) oak or acacia (Robinia), each of which is capable of posing a threat to local flora.

${ }^{5}$ After Poland lost its independence at the end of the 18th century, these large forest complexes were taken over by the partitioning powers and occupants, and were more intensively exploited, but also fulfilled similar functions.
} 
line with the fact that conflicts with the owners of peasant plots were likely to be less severe.

Woods and forests that belonged to the minor nobility or to peasants have been used intensively over the centuries (with dry twigs collected, litter raked, small trees cut, animals grazed, bark taken off trees, wood exploited, and berries, mushrooms and herbs collected). Ultimately, though, most of these woods and forests were in any case felled and turned into farmland.

\section{The appropriation of land and the borders of property}

Both large landowners and petty holders of plots have been delimiting their territory for centuries. The manner of demonstrating where a border runs has changed over time and space. The oldest border marks in central Europe were constituted by boulders and stone mounds, while border poles were being placed out as early as in the 11th century (e.g. in the channel of the Oder). In the Middle Ages and the Renaissance period the borders between ethnic groups in conflict with one another were associated with wide zones of 'no-man'sland' - large, thinly populated areas, overgrown with forests, often times swampy. Chains of large forests separated the region of Masovia from Prussia and Lithuania to the north, while the forests of the Carpathians formed a buffer defending the region of Małopolska from the the expansion of the Czechs, Hungarians and Ruthenians living to the south. Today's state boundaries are marked in the landscape by the sequence of border posts or poles, while in the case of Poland's northern and eastern borders (other than along a short segment of the boundary with Lithuania) these are accompanied by a belt of mowed meadows, ploughed zones, fenced with barbed wire. This contemporary boundary of the European Union is visible not just in the field, but readily also in aerial and satellite imagery.

In older times, for reasons associated with defence, towns were walled, while at the ends of villages gates were erected, making it difficult for uninvited guests to gain access after sunset. Individual farm plots were fenced in villages from the side of the road and the neighbouring farmyards, but vegetable gardens, orchards and fields were not fenced (which did not mean there were no border conflicts and so-called 'balk disputes'). In-field trees, stone mounds, balks, characteristic bush belts and hedges - all of these served to distinguish the boundaries of territories of smallscale landholders. In areas of diversified relief, the balks, yet emphasised by ploughing terraces emerging through cultivation at the limits of fields constitute a permanent element of the landscape bearing witness to the division of land among different properties.

A characteristic feature of the communist period in the countries of Central Europe (19451990) was a process of liquidation of the internal boundaries within countries. Landscape was divided up by fences to only a very limited degree, with many older walls and fences demolished. Upon the liquidation or takeover of the landed estates, the fences around parks were destroyed, and the parks themselves made accessible to inhabitants. Forests were entirely taken over by the state, and the citizens were allowed to penetrate them freely. It was the intention of the authorities that this might symbolise society's common property, while at the same time reinforcing the power of the communists themselves.

After capitalism had been brought back and private property 'ennobled' once more, landscape started to be divided up anew to a much more significant degree - fences surround not only house and yard, but also some agricultural plots (e.g. orchards, meadows, and pastures), and even divide up the forest complexes and limit access to the shores of bodies of water ${ }^{6}$. Housing estates are in turn being walled or fenced off. Solid plates, wire nets, grilles, or walls divide the space between owners, constituting an architectural barrier that hampers the migration of wild animals and movement of people alike, also splitting up and often impairing the outlook of the landscape. It is a great achievement, indeed, that the majority of forests have not been privatised until now in Poland, and that forest complexes are not in general crossed by fences, and are commonly accessible.

\section{The stamps of authority and ownership imprinted in the landscape structure}

The structure of the landscape is its backbone, and the structural lines are very persistent. In many places historical settlement patterns have been preserved, along with the specific settings

\footnotetext{
${ }^{6}$ This being against the Polish law.
} 
of buildings in farmyards, and the courses of local roads, balks and in-field bush lines, maintained in line with tradition (Pietrzak 2002; Skowronek 2005; Plit 2009). Numerous localities have preserved their historical spatial patterns. Bogdanowski (1998) distinguishes and characterises the architectural settings dating from various historical periods. The Gothic plans of the castles of the Teutonic Orders, the Hanseatic structures of the old cities of Toruń and Gdańsk, the Renaissance landscape of Zamość and Kazimierz on the Vistula, the Baroque designs of the residential developments and parks along axes of composition (as in Wilanów and in the Saxon Garden in Warsaw), the Classicist designs with French, Italian or English style parks (Łazienki in Warsaw, Puławy and Kórnik), as well as many mixed designs, changing over the centuries, in which features of various periods and fashions are superimposed.

Both towns and villages have had and retain their representative quarters, as well as uglier parts, less cared-for (in earlier times the latter were usually peripheral fragments, but nowadays they are also neglected centres that often become depopulated). The proper frontline is, as a rule, composed of government buildings, a church and the residences of rich landowners. As one comes in along the main road, one encounters a nice view, meant for the representative part of the locality (Mezer 2009). The 'frontline' of the city has changed many times over. Warsaw is a good example in these terms (Fig. 3). ${ }^{7}$ The general rule of the division of space was valid in olden times and still retains its validity: the 'front part' of the

\footnotetext{
7 The city developed with its frontline overlooking the River Vistula - the most exquisite buildings, palaces and churches were situated at the edge of the valley slope, ensuring a beautiful view from the riverside. Later on, the representative road was the one leading from the Royal Castle southwards towards Cracow (via the streets of Krakowskie Przedmieście and Nowy Świat, down into suburban Wilanów), along which representative buildings were erected. During Poland's period under the Kings of Saxony (in the first part of the 18th century) the most important route was that heading for Dresden - and so a broad axis was established, bordered by trees, across a vast court park (nowadays the Saxon Garden), heading straight in a westerly direction. After World War II, a similar representative function was taken on by the broadened (and northwards-extending) Marszałkowska Street, with buildings in the Socialist-Realist style, the Palace of Culture and the Central Railway Station, all of which symbolised the newly-established order. Today the representative area is more extensive, though the majority of imposing skyscrapers are erected in the downtown area along the streets not far from Marszałkowska.
}

city used to be not only more beautiful, but also safer. The inhabitants of the medieval towns, who lived in the boroughs, outside the city walls, were poorer, their occupations entailing the rendering of services to the wealthier, and being subject to the risk of aggression. Nowadays, the representative buildings and the historical downtowns are taken care of, with best-quality materials used even for sidewalks, and with illumination during the night time. In contrast, the peripheries, slums, old industrial quarters and so on are often neglected, dark and dirty, and are considered more dangerous.

\section{The arbitrary decisions of the authorities}

It is not only economic and political, but also landscape-related, effects of the activity of the authorities that have arisen as a consequence of the arbitrary decisions taken by those in power, as regards the courses of roads and railways, and the locations of large industrial plants, waste dumps, large-scale dams and reservoirs. This was particularly true of the communist period, during which, through the construction of - say - a metalworking combine or a mining district (and hence the associated inflow of blue-collar workers from other regions) cultural continuity might be broken and the traditions of a given region intentionally weakened (as in the case of the Nowa Huta steel-working plant in Cracow). All decisions concerning the location of large-scale investment projects had far-reaching consequences for the physiognomy of the landscape and for its functioning. Even more important were settlement or deportation actions, not to mention those leading to the liquidation of groups of inhabitants. These affected strongly, or even actually determined, further development paths. Thus, the traces of many centuries of the presence of Jews disappeared from Central Europe. The areas of Poland around Przemyśl, in the Lower Beskidy Mts. and in the Bieszczady Mts. were depopulated and afforested as Ukrainians and Ruthenians were deported. Masuria, Western Pomerania, the Sudetes (especially the Rudawy Mts.) all also emptied out as the German population was driven away. The churches of various denominations changed in terms of the faithful frequenting them. Gradually, also old cemeteries, forgotten and sometimes even devastated, have disappeared, often 


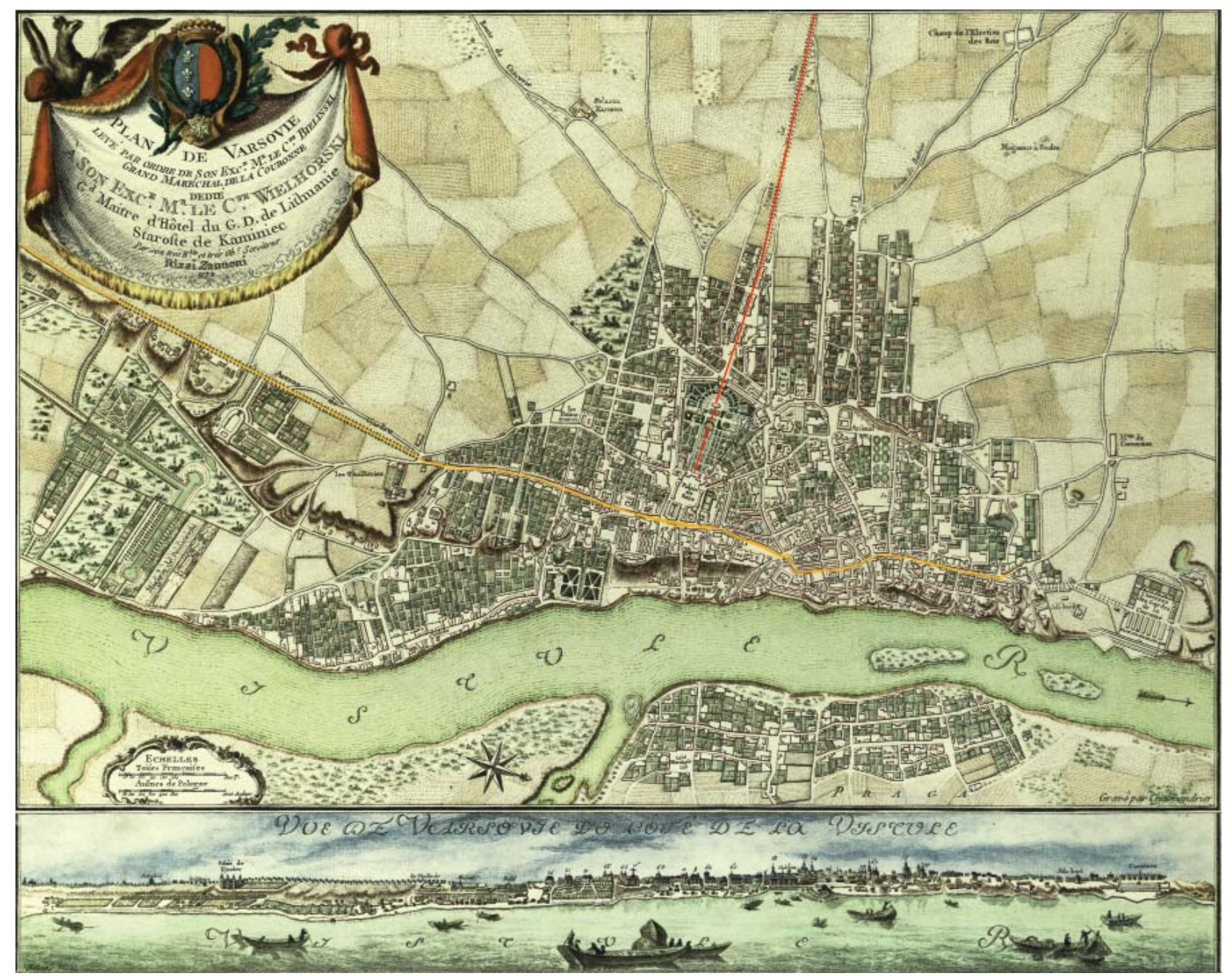

Figure 3. Zannoni's plan and panorama of Warsaw on a scale of c. 1:17,500 dating from 1772. Colours are used to emphasise the changing locations of the city's 'foremost' part: in yellow the Royal Way (Trakt Królewski) and in red the 'Saxon Axis' (Oś Saska). 
becoming overgrown with forest. Praiseworthy exceptions are provided by the places in which the graves of former inhabitants are still looked after conscientiously (Fig. 4).

\section{Summary}

Cultural landscape can be treated as an iconographic record, not only of the history of a given region in general, but also of the changes of authority in the same area. Landscape preserves the aspirations of those in power and the rich, in terms of appropriation of space, and the delimitation of boundaries of respective territories achieved through the erecting of border stones and roadside crosses, but also through the maintenance of wastelands. Landscape conserves evidence of inspirations and of ways of wielding power. The scheme below demonstrates the features of authority and ownership that are reflected in the cultural landscape, and, on the other hand the types (and locations) of elements of the landscape one can look to for signs of their influence. It should be remembered, though, that as time passes there is indeed a change in the forms and intensities of particular interrelations (as marked with arrows) (Fig. 5).

Rulers and owners left footprints - i.e. stamps of their rule and activity - in cultural landscape. Their decisions and deeds marked in a strong and persistent manner the elements of the landscape, exerting an essential influence on the physiognomy and functioning of landscapes. The motivations of rulers and owners were often negative (pride, or a desire to dominate and display supremacy, as well as intimidate and impose), but the effects of their activity and decisions, as seen in the landscape, are quite frequently assessed in a positive manner today. It is the palaces and the churches, as well as the strongholds, that have persisted through the stormy history of our country, and it is these that successive generations restore carefully after fires or bombings, in an acknowledgment of the way they bear witness to the history and culture of our nation.

Editors' note:

Unless otherwise stated, the sources of tables and figures are the author(s), on the basis of their own research.

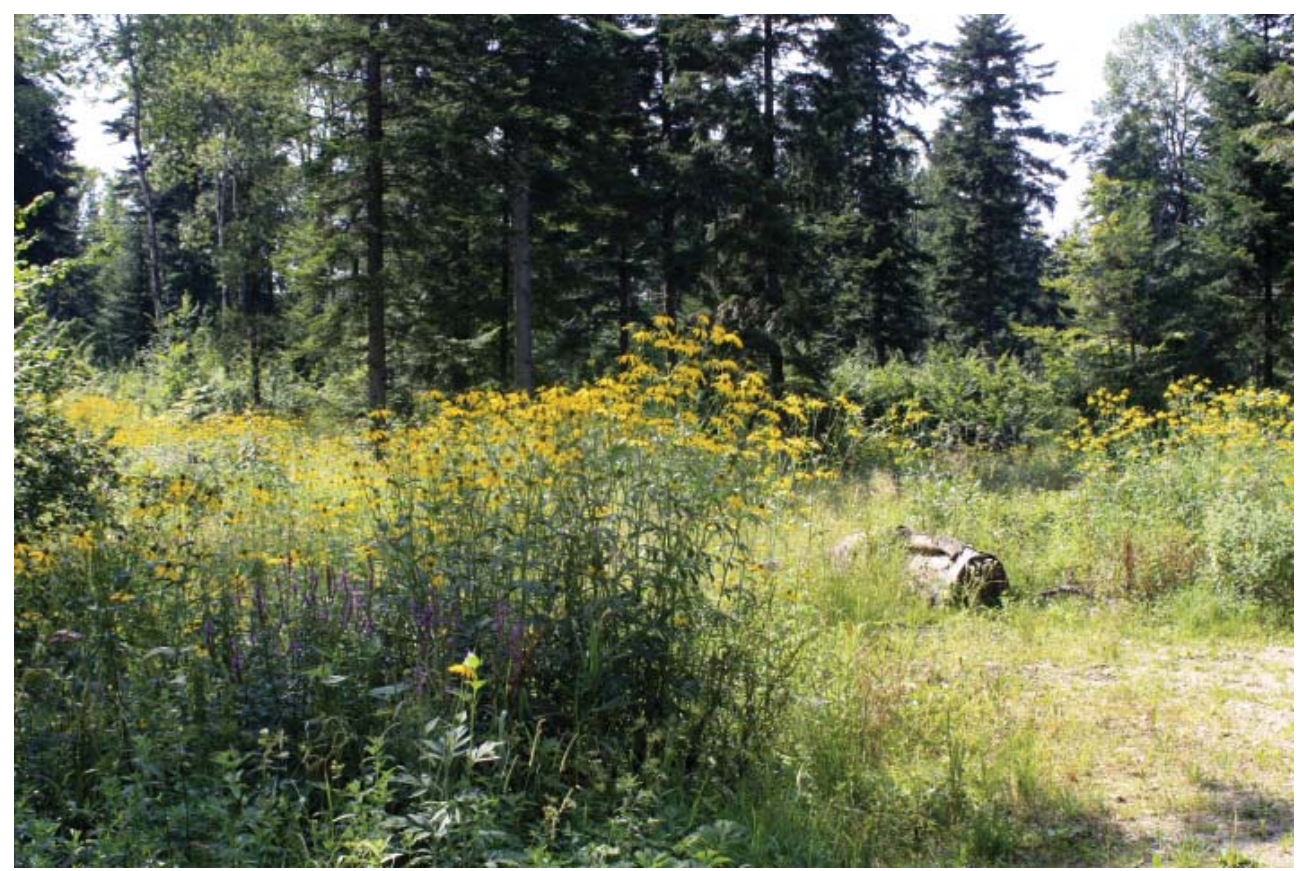

Figure 4. The expulsion of the population from the region around Przemyśl was followed by the regrowth of forest. However, the locations of the former villages are attested to, not only by the remaining foundations of the former buildings, but also by the still-detectable presence of fruit trees and flowers that once grew in gardens. 
Motivations of rulers and owners

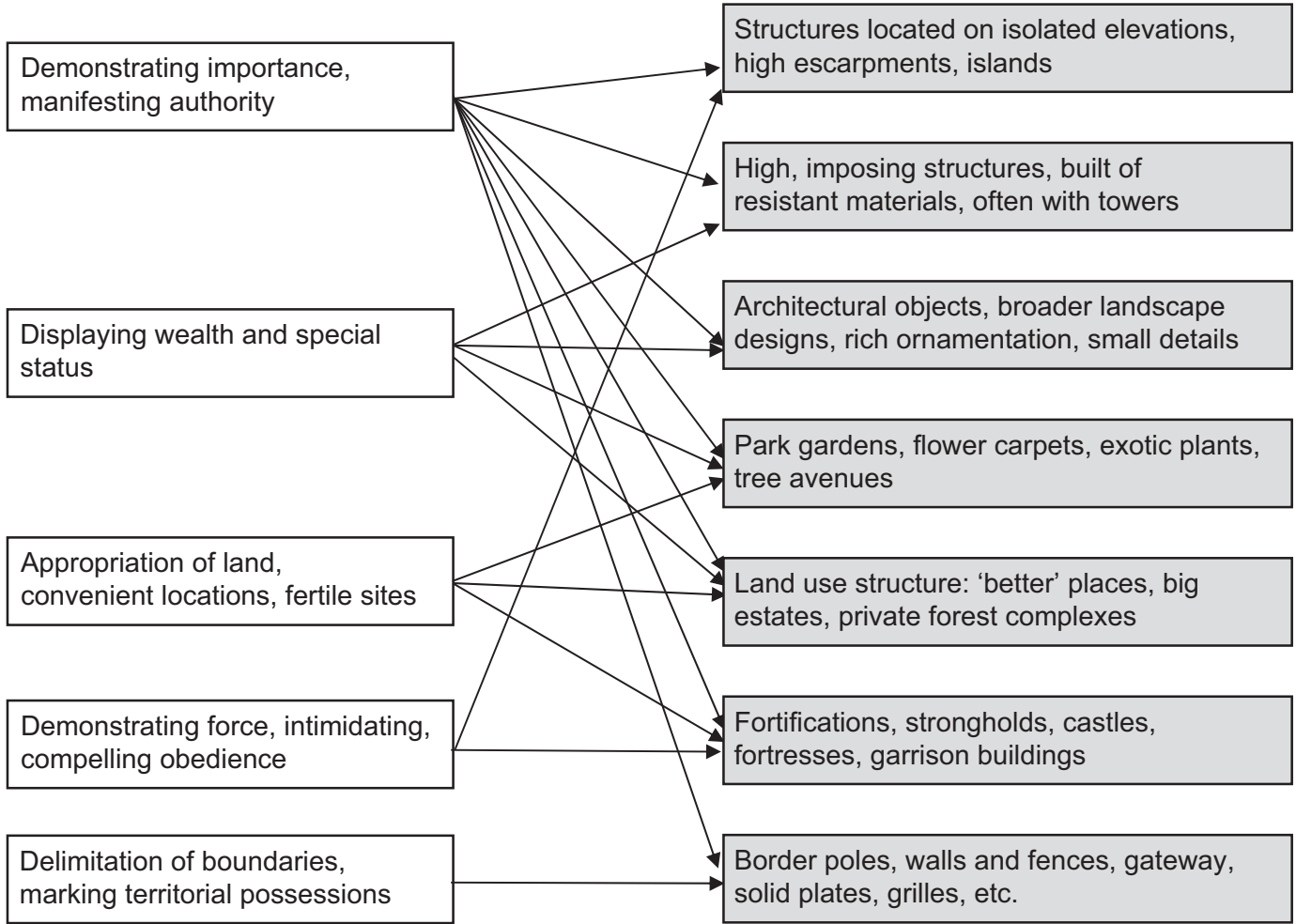

Figure 5. Scheme of connections between motivations of rulers and owners and effects of their activity on landscape.

\section{References}

Bender B. (ed.), 1993. Landscape. Politics and perspectives. Providence: Berg, 351 pp.

BogDANOWSKI J., 1998. Konserwacja i ochrona krajobrazu kulturowego (ewolucja metody). Teki Krakowskie, no. 6, Kraków: Regionalny Ośrodek Studiów i Ochrony Środowiska Kulturowego, 259 pp.

Braudel F., 1969. Ecrits sur l'histoire. Paris: Flammarion, $314 \mathrm{pp}$.

Chludziński A., 2007. Nazwy miejscowe gminy Darłowo. [in:] W. Raczkowski, J. Sroka (eds.), Historia i kultura Ziemi Sławieńskiej, vol. 6, Sławno: Fundacja "Dziedzictwo", pp. 57-104.

CZEPCZYŃ́ski M., 2006. Przemiany form i znaczeń krajobrazów kulturowych miast socjalistycznych. [in:] W. Wołoszyn (ed.), Krajobraz kulturowy: cechy, walory, ochrona, Problemy Ekologii Krajobrazu, vol. 18, Lublin: Zakład Ochrony Środowiska UMCS, pp. 59-66.

Dobrowolska M., 1948. Dynamika krajobrazu kulturalnego. Przeglad Geograficzny, vol. 21, no. 3-4, pp. 152-203.

GACKI J., 1872. Benedyktyński klasztor w Sieciechowie według pism i podań miejscowych. Radom: Trzebiński, 299 pp.

Kostrowicki A.S., Solon J. (eds.), 1994. Studium geobotaniczno-krajobrazowe okolic Pińczowa. Dokumentacja Geograficzna, no. 1-2, Warszawa: Instytut Geografii i Przestrzennego Zagospodarowania PAN, $189 \mathrm{pp}$.

MCManN J., 1994. Forms of power: Dimensions of an Irish megalithic landscape. Antiquity, vol. 68, no. 260, pp. 525-544.

Mezer E., 2009. Konsekwencje zmiany rangi dawnych traktów we współczesnym układzie komunikacyjnym 
na przykładzie wsi Raczkowo. [in:] Z. Kuriata (ed.), Polskie krajobrazy wiejskie dawne i współczesne, Prace Komisji Krajobrazu Kulturowego PTG, no. 12, Sosnowiec: Komisja Krajobrazu Kulturowego PTG, pp. 150-157.

MuIR R., 2000. The new reading the landscape: Fieldwork in landscape history. Exeter: University of Exeter Press, 256 pp.

Myga PiĄtek U., 2001. Spór o pojęcie krajobrazu w geografii i dziedzinach pokrewnych. Przegląd Geograficzny, vol. 73, no. 1-2, pp. 163-176.

Myga-PiąteK U., 2012. Krajobrazy kulturowe. Aspekty ewolucyjne $i$ typologiczne. Katowice: Uniwersytet Ślq̨ski, 402 pp.

Pietrzak M., 2002. Geomorfologiczne skutki zmian użytkowania ziemi na Pogórzu Wiślickim. Przemiany środowiska na Pogórzu Wiślickim, vol. 2, Kraków: Instytut Geografii i Gospodarki Przestrzennej UJ, $147 \mathrm{pp}$.

PLit J., 2002. Zmiany biegu Wisły na odcinku od Stężycy do Magnuszewa i ich skutki. [in:] A.T. Jankowski, U. Myga-Piątek, G. Jankowski (eds.), Problemy ochrony i kształtowania krajobrazu Górnego Śląska na tle doświadczeń z innych regionów Polski, Prace Komisji Krajobrazu Kulturowego PTG, no. 1, Sosnowiec: Wydział Nauk o Ziemi Uniwersytetu Śląskiego, pp. 143-151.

PLIT J., 2009. Tradycyjny krajobraz wiejski wschodniego Podlasia na przykładzie "Krainy otwartych okiennic". [in:] Z. Kuriata (ed.), Polskie krajobrazy wiejskie dawne i współczesne, Prace Komisji Krajobrazu Kulturowego PTG, no. 12, Sosnowiec: Komisja Krajobrazu Kulturowego PTG, pp. 47-57.

PLIT J., 2011. Piętno władzy i właścicieli odciśnięte w krajobrazie kulturowym. [in:] S. Bernat (ed.), Niematerialne wartości krajobrazów kulturowych, Prace Komisji
Krajobrazu Kulturowego PTG, no. 15, Sosnowiec: Komisja Krajobrazu Kulturowego PTG, pp. 125-138.

Skowronek E. (ed.), 2005. Wpływ działalności gospodarczej wielkich majątków ziemskich na stan współczesny dziedzictwa kulturowego. Lublin: Wydawnictwo UMCS, 181 pp.

Stepaniuk M., Gawet A., 2006. Granice między krajobrazami kulturowymi w regionie Puszczy Białowieskiej. [in:] J. Plit (ed.), Granice w krajobrazach kulturowych, Prace Komisji Krajobrazu Kulturowego PTG, no. 5, Sosnowiec: Komisja Krajobrazu Kulturowego PTG, pp. 158-171.

TILLEY C., 1994. A phenomenology of landscape. Places, paths and monuments, Oxford-Providence: Berg, $221 \mathrm{pp}$.

Tilley C., 2008. Phenomenological approaches to landscape archaeology. [in:] B. David, J. Thomas (eds.), Handbook of landscape archaeology, Walnut Creek (Calif.): Left Coast Press, pp. 271-276.

TUAN YI-Fu, 1978. Literature and geography: Implications for geographical research. [in:] D. Ley, M. Samuels (eds.), Humanistic geography: implications for geographical research: prospects and problems, Chicago: Maaroufa Press, pp. 194-206.

TUAN YI-Fu, 2005. Space and place, The perspective of experience. University of Minnesota Press, Minneapolis: University of Minnesota Press, 235 pp.

van Dyke R.M., 2008. Memory, place, and memorialization of landscape. [in:] B. David, J. Thomas (eds.), Handbook of landscape archaeology, Walnut Creek (Calif.): Left Coast Press, pp. 277-284. 
http://rcin.org.pl 